\title{
Tirozinaz Enziminin Giresun Yöresinde Yetişen Yenilebilir Kanlıca Mantarından (Lactarius salmonicolor) Saflaştırılması ve Karakterizasyonu
}

\author{
Bahar BİLGIN SÖKMEN ${ }^{1 *}$, Betül YILMAZOĞLU ${ }^{1}$ \\ ${ }^{1}$ Giresun Üniversitesi, Fen Edebiyat Fakültesi, Kimya Bölümü, 28100, Giresun, TÜRKIYE
}

Geliş Tarihi:03.04.2018

*Sorumlu Yazar: bahar.sokmen@giresun.edu.tr

Kabul Tarihi:20.06.2018

\section{$\ddot{\mathbf{O z}}$}

Tirozinaz (EC. 1.14.18.1) funguslarda, yüksek bitkilerde ve hayvanlarda bulunan; moleküler oksijenin etkisiyle monofenollerin o-difenollere hidroksilasyonu; o-difenollerin de o-kinonlara oksidasyon reaksiyonlarını katalizleyen ve bakır içeren bir enzimdir. Bu çalışmada, Giresun İli ve çevresinde bol miktarda yetişen Kanlıca Mantarından (Lactarius salmonicolor) tirozinaz enzimi ilk defa saflaştırıldı ve kinetik özellikleri incelendi. Optimum pH ve sıcaklık değerleri, $\mathrm{pH}$ ve sicaklık stabiliteleri, optimum reaksiyon süresi, optimum reaksiyon süresinin tayini, uygun enzim ve substrat konsantrasyonu belirlendi. Kanlıca mantarından saflaştırılan tirozinazın optimum pH'sının 6,0; optimum sıcaklığının $40^{\circ} \mathrm{C}$ olduğu bulundu. SDS-PAGE elektroforezi sonucunda saflaştırılan enzimin molekül ağırlığının $30 \mathrm{kDa}$ olduğu bulundu. L. Salmonicolor tirozinaz enziminin optimum $\mathrm{pH}$ ve sıcaklıkta L-tirozin substratı için $\mathrm{K}_{\mathrm{m}}$ ve $\mathrm{V}_{\max }$ değerleri Linewear-Burk yöntemi ile bulunmuştur.

Anahtar Kelimeler: Kanlıca Mantarı (Lactarius salmonicolor), Tirozinaz, Saflaştırma, Karakterizasyon.

\section{Purification and Characterization of Tyrosinase Enzyme from the Edible Kanlıca Mushrooms (Lactarius salmonicolor)}

\begin{abstract}
Tyrosinase (EC 1.14.18.1) is an enzyme containing copper that found in fungi, high plants and animals. Furthermore, it is catalyses there actions oxidation to o-quinones of o-diphenols and hydroxylation of monophenolsto o-diphenols using molecular oxygen. In this study, tyrosinase enzyme was purified for the first time from Kanlica Mushroom (Lactarius salmonicolor) plenty of grown in Giresun Province and around and examined the kinetic properties. Optimum $\mathrm{pH}$ and temperature, $\mathrm{pH}$ and temperature stability, optimum reaction time, determining the optimum reaction time was the appropriate enzyme and substrate concentrations. The optimum $\mathrm{pH}$ of the purified tyrosinase from mushroom Kanlica 6.0 was found to be optimal at $40^{\circ} \mathrm{C}$. The purified enzyme, which showed SDS-PAGE, had a molecular weight of 30 $\mathrm{kDa}$. The $\mathrm{K}_{\mathrm{m}}$ and $\mathrm{V}_{\max }$ values of L. Salmonicolor tyrosinase toward were determined by Lineweaver Burk method.
\end{abstract}

Keywords: Kanlica Mushroom (Lactarius salmonicolor), Tyrosinase, Purification, Characterization. 


\section{Giriş}

Tirozinaz (polifenoloksidaz (PFO),EC.1.14.18.1); funguslarda, yüksek bitkilerde ve hayvanlarda bulunan; moleküler oksijeni kullanarak monofenollerin o-difenollere hidroksilasyonunu; odifenollerinde o-kinonlara oksidasyonunu katalizleyen ve bakır içeren bir enzimdir. Tirozinaz, bitkiler, bakteriler ve memeliler de olmak üzere çok sayıda canlı grubunda bulunan bir enzimdir. Krezolaz ve katekolaz aktivitesi olmak üzere iki ayrı aktiviteye sahiptir. Tirozinazlar, oksidoredüktaz sınıfı enzimlerdir ve bakır kofaktörlüdürler. Moleküler oksijenin varlığında o- ve vic-OH gruplu (3,4,5-trihidroksi) fenolik bileşiklerinin oksitlenme reaksiyonlarına ek olarak monofenollerin o-dihidroksifenollere dönüştürülmesinde de rol oynamaktadırlar (VamosVigyazo, 1981). İlk olarak Schoenbein tarafından 1856 yllında yemeklik mantarlarda olduğu bildirilmiştir. Daha sonra birçok meyve ve sebzede tirozinaz belirlenmiş ve karakterize edilmiştir (Keleş, 1987).

Tirozinazlar, bitkilerin mikrobiyal yada viral enfeksiyonlara karşı direnç göstermesinde oldukça önemli role sahiptir. Ayrıca, bitkilerin muhtemel elverişsiz iklim koşullarına karşı dayanıklı olmalarının bir sebebi de tirozinazların varlığıdır. Gıda teknolojisi açısından tirozinaz önemli bir enzimdir. Tirozinaz aktivitesine sahip bazı gıda maddeleri; çay, muşmula, patlıcan, Cassava bitkisi, ananas, çilek, enginar, elma, zambak, Anamur muzu ve Napoleon üzümü ve çilek olarak sayılabilir. Bitkilerdeki tirozinaz miktarı çeşidine, yaşına, kültürel işlemleri ve olgunluğuna bağlıdır (Spille, 1997).

Tirozinaz ve polifenoller bitkilerde yaygın olarak bulunmaktadır. Bunun dışında çeşitli mikroorganizmalarda (Bazı bakteri ve küf çeşitlerinde), özellikle mantarlarda ve bazı hayvansal organizmalarda da bulunabilir (Vamos-Vigyazo, 1981). Tirozinaz sanayi, kağıt hamuru ve kağıt sanayi, tekstil sanayi, ilaç ve çevre teknoloji bazı biyoteknolojik uygulamalar için çok uygundur.

Tirozinaz sanayi, kağıt hamuru ve kağıt sanayi, tekstil sanayi, ilaç ve çevre teknoloji bazı biyoteknolojik uygulamalar için çok uygundur. Gıda endüstrisinde, tirozinazlar için hiç arzu edilmez; ancak bu enzimlerin esmerleşme etkileri, çeşitli faydalı amaçlar için kullanılmaktadır. Tirozinaz, özellikle laktazlarla ilgili çapraz bağ biyopolimerleri elde edilebilir. Ayrıca antioksidan ve besin renklendirici biyosentezi gıda da değişik yönleriyle tirozinazların uygulamaları sanayi, renk oluşumu ve çay, kakao ve kahve lezzet geliştirmesini içerir ve askorbik asit tayini, şeker pancarı, pektin jelleşme ve biyosensör olarak uygulanırlar (Şimşek ve Yemenicioğlu, 2007).

Yenilebilir ve şapkalı bir mantar olan L. salmonicolor, mantarlar aleminin Homobasidiomycetae sınıfı, Russulales takımının Russulacea familyasına aittir. Genel görünüşü, turuncu ve sarıdan oluşan halkalı bir yapısı vardır. Şapka büyüklüğü 5-15 cm kadardır. Rengi turuncudur (Ramsbottom, 1953). 
Eylül ve Ekim aylarında yağmurlardan sonra ortaya çıkan bu mantar halk arasında "Melki" ya da "Kanlıca Mantarı" olarak adlandırılır. Türkiye'de yerel halk bu mantarı toplayıp pazarlarda satarlar, ayrıca bu mantar çeşitli Avrupa ülkelerine de ihraç edilir. Zayıflamak isteyen kişiler için mantarları ideal bir gıda niteliğindedir. Öte yandan, mantarlar kalp ve damar hastalıkları bulunan kişiler için de tavsiye edilen bir yiyecektir.

$\mathrm{Bu}$ çalışmada, Giresun yöresinde yetişen Kanlıca Mantarından (L. salmonicolor) tirozinaz enzimi ilk kez saflaştırıldı ve bazı kinetik özellikleri incelendi.

\section{Materyal ve Metot}

\subsection{Kullanılan Kimyasallar}

Kanlıca Mantarı (L. salmonicolor)'ndan ham ekstre hazırlanmasında dipotasyum hidrojen fosfat (Merck) ve potasyum dihidrojen fosfat (Merck)'tan yararlanıldı. Amonyum sülfat kesiti için amonyum sülfat (Sigma) ve Sigma marka \{D-9527 genişliği 43 mm (1,711), çapı $27 \mathrm{~mm}(1,111)\}$ dializ kesesi kullanıldı. DEAE-selüloz kolon kromatografisinde, kolon dolgu maddesi olarak DEAE-selüloz (Sigma) kullanıldı. Ham ekstrede, amonyum sülfat ve DEAE-selüloz kolon kromatografisinden elde edilen fraksiyonlarda, enzim aktiviteleri ve protein tayinlerinde hidrojen peroksit $\left(\mathrm{H}_{2} \mathrm{O}_{2}\right)$ (Merck), sığır serum albumini (Merck), Folin ayıracı (Merck), bakır sülfat (Sigma), dipotasyum tartarat (Sigma), sodyum karbonat (Merck), sodyum hidroksit, dipotasyum hidrojen fosfat ve potasyum dihidrojen fosfat (Merck)'tan yararlanıldı. Sodyum dodesil sülfat-poliakrilamid jel elektroforezi (SDS-PAGE)'nde jellerin hazırlanmasında Tris (hidroksimetilaminometan), hidroklorik asit, N,N'-metilen-di-akrilamidakrilamid, $\beta$-merkapto etanol, brom timol mavisi, glisin, Coomassie Brilliant Blue R250, metanol, asetik asid (Merck), SDS, N,N,N',N'-tetrametil etilen diamin (TEMED), amonyum persülfat, gliserin ve marker kiti (Sigma) kullanıldı.

\subsection{Kullanılan Cihazlar}

Hazırlanan ekstrelerin ve DEAE-selüloz kolon kromatografisi çıkışında elde edilen fraksiyonların saklanmasında Arçelik marka Nofrost ve dondurucusu kullanıldı. Absorbans ölçümleri, Shimadzu UV Mini-1240 model UV-VIS Spektrofotometrede okundu. Blender King, pH metre Butech, hassas terazi Sartorius, manyetik karıştırıcı Chiltern Hotplate HS 31, vorteks Velp Scientifica, su banyosu Memmert, sonik su banyosu Selectra, soğutuculu santrifüj Sigma 3K 30, molekül ağırlığı tayini Bio-Rad Marka elektroforez cihazıyla yapıldı. 


\subsection{Kanlıca Mantarı Ham Ekstresinin Hazırlanması}

Ham ekstre hazırlamak için Blender yardımıyla parçalanmış $100 \mathrm{~g}$ yenilebilir Kanlıca mantarı $500 \mathrm{~mL} 200 \mathrm{mM}$ fosfat tamponu $(\mathrm{pH}=7,0)$ içinde $+4{ }^{\circ} \mathrm{C}$ 'de manyetik karıştırıcı ile 1 saat karıştırıldıktan sonra, ağzı kapatılarak bir gece bekletildi. Ertesi gün homojenizat iki kat bezden süzüldü. $0{ }^{\circ} \mathrm{C}^{\prime}$ de 18000 rpm'de, 30 dakika santrifüj edildi. Üstteki berrak kısım alındı. Bu işlemlerin sonucunda Kanlıca mantarı ham ekstresi elde edildi. Ham ekstrede tirozinaz aktivitesi ve protein miktar tayinleri yapıld1.

\subsection{Amonyum Sülfat Çöktürmesi, Diyaliz, Dietilaminoetil (DEAE)-Selüloz Kolon Kromatografisi}

Kanlıca mantarı için en uygun amonyum sülfat konsantrasyonunu saptamak üzere \% $10-90$ aralığında çöktürme yapıldı. Amonyum sülfatı uzaklaştırmak amacıyla diyaliz kesesine konuldu. +4 ${ }^{\circ} \mathrm{C}$ 'de, 0,01 M fosfat tamponu ( $\left.\mathrm{pH}=7,0\right)$ ile çözelti sık sık değiştirilerek ve manyetik karıştırıcı ile karıştırılarak, çözeltide sülfat iyonu kalmayıncaya kadar dializ işlemine devam edildi. DEAEselüloz kolonuna yaklaşık $200 \mathrm{mg} / \mathrm{mL}$ protein olarak \% 60 amonyum sülfat kesiti uyguland. Kolondan sırasıyla yaklaşık $200 \mathrm{~mL}$ 0,5 mM fosfat tamponunda çözülmüş $10 \mathrm{mM}, 20 \mathrm{mM}, 50 \mathrm{mM}$, $100 \mathrm{mM}, 200 \mathrm{mM}, 300 \mathrm{mM}$ ve $500 \mathrm{mM} \mathrm{NaCl}$ gradienti uygulandı. Fraksiyonlar her tüpte eşit hacim olacak şekilde toplandı (4-5 mL). Tüplerdeki çözeltilerin absorbansları, elüe edilen tampona karşı spektrofotometrede, $280 \mathrm{~nm}$ 'de okunarak elüsyon grafiğgi çizildi. Ayrıca elüsyonlardaki tirozinaz aktivitesi tayin edilerek aktivite değerleri de aynı grafikte gösterildi. Enzimatik aktivite gösteren tüplerdeki çözeltiler bir araya toplandı ve bu çözeltinin tirozinaz aktivitesi ve protein miktar tayini yapıldı. Çözelti uygun hacimlere bölünerek, daha sonra kinetik özellikleri incelemede kullanılmak üzere derin dondurucuda saklandı.

\subsection{Protein Miktar Tayini}

Kanlıca Mantarından tirozinaz enziminin saflaştırılması sırasında, ham ekstre ve \% 60'lık amonyum sülfat fraksiyonunun elde edilmesi evrelerinde, protein miktarı Lowry ve arkadaşlarının yöntemine göre tayin edildi (Lowry ve ark., 1951). DEAE-selüloz kolon kromatografisi ile elde

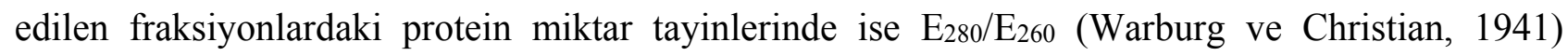
kullanıldi. 


\subsection{Tirozinaz Aktivitesinin Tayini}

Enzim aktivitesi, $30{ }^{\circ} \mathrm{C}$ sıcaklıkta 40 sn boyunca absorbanstaki artışın 400 nm'de ölçülmesiyle tayin edilmiştir. Enzim aktivitesi, absorbans-zaman grafiğinin doğrusal kısmının eğiminden hesaplanmıştır. Aktivite deneyleri, iki kez tekrar edilmiş ve sonuçlar ortalama değerler olarak ifade edilmiştir. pH'ı 7 olan 0,2 M fosfat tamponu ile hazırlanmış ve $30^{\circ} \mathrm{C}^{\text {'ye }}$ ısıtılmış 0,9 $\mathrm{mL}$ substrat çözeltisi $0,1 \mathrm{~mL}$ enzim çözeltisi ile karıştırıldıktan sonra absorbanstaki artış kaydedilmiştir. 1 ünite tirozinaz aktivitesi $30{ }^{\circ} \mathrm{C}$ 'de dakikada 0,001 birimlik absorbans artışını sağlayan enzim miktarı olarak tanımlanmıştır (Ünal ve Şener, 2006).

\subsection{SDS - PAGE İle Enzim Saflığının Kontrolü}

Kanlıca Mantarı tirozinazı, DEAE-selüloz kolon kromatografisi ile saflaştırıldıktan sonra yı̆̆ma jeli \% 3, ayırma jeli ise \% 10 konsantrasyonlarında olacak şekilde kesikli SDS-PAGE jel elektroforezi ile enzimin saflık derecesi kontrol edildi (Laemmli, 1970). Enzimin molekül ağırlığı standart proteinlerin molekül ağırlıkları yardımıyla grafikten hesaplandı.

\subsection{Kanlıca Mantarından Elde Edilen Tirozinazın Enzim Aktivitesine Göre Kinetik Özelliklerinin İncelenmesi}

\subsubsection{Tirozinaz Aktivitesi Üzerine pH'nın Etkisinin İncelenmesi}

Enzimin en yüksek aktivite gösterdiği optimum pH’yı tespit edebilmek için, pH 3,0-10,0 aralığında aktiviteler tayin edilmiştir. Tampon olarak sitrik asid-NaOH ( $\mathrm{pH}=3-5$ aralığı), sodyum fosfat $(\mathrm{pH}=6-8$ aralı̆̆ 1$)$ ve glisin- $\mathrm{NaOH}(\mathrm{pH}=9-10$ aralığ 1$)$ çözeltileri kullanıldı. Enzimlerin en yüksek aktivite gösterdiği $\mathrm{pH}$ değeri optimum $\mathrm{pH}$ olarak belirlendi.

\subsubsection{Tirozinaz Aktivitesi Üzerine Sıcaklı̆̆ın Etkisinin İncelenmesi}

Optimum sıcaklığ 1 tayin edebilmek için enzimin $20-70{ }^{\circ} \mathrm{C}$ arasındaki sıcaklıklarda aktiviteleri ölçüldü. Enzim çözeltisi, 20-70 ${ }^{\circ} \mathrm{C}$ arasındaki sıcaklıklarda ayrı ayrı su banyosunda 5 dakika bekletildi. Optimum pH'daki tamponla hazırlanan $0,9 \mathrm{~mL}$ substrat çözeltisine, $0,1 \mathrm{~mL}$ enzim çözeltisi ilave edilerek enzimlerin aktiviteleri tayin edildi. Enzim aktivitesinin maksimum olduğu sıcaklık değeri optimum sıcaklık olarak belirlendi. 


\subsubsection{Uygun Reaksiyon Süresinin Bulunmast}

Tirozinaz aktivitesinin uygun reaksiyon süresinin bulunması amaciyla substrat, enzim ve tampon çözeltilerden aktivite tayin yönteminde belirtilen miktarlarda alınarak reaksiyonun 1, 5, 10, 15, 20, 25 ve 30. dakikalarında tirozinaz aktivitesi tayin edildi.

\subsubsection{Enzim Konsantrasyonunun Tirozinaz Aktivitesine Etkisi}

Enzim konsantrasyonunun tirozinaz aktivitesine etkisini incelemek amaciyla enzim çözeltisi, 180-1080 $\mu \mathrm{L}$ arasında değişen hacimlerde alınarak 400 nm'de 5 dakika beklenerek ölçüm yapıldı ve tirozinaz aktivitesi tayin edildi.

\subsubsection{Substrat Konsantrasyonunun Tirozinaz, Aktivitesine Etkisi}

Substrat konsantrasyonunun tirozinaz aktivitesine etkisini incelemek amaciyla enzim çözeltisi, 180-1080 $\mu \mathrm{L}$ arasında değişen hacimlerde alınarak 400 nm'de 5 dakika beklenerek ölçüm yapıldı ve tirozinaz aktivitesi tayin edildi.

\section{Bulgular ve Tartışma}

\subsection{Uygun Amonyum Sülfat Konsantrasyonu ve DEAE-Selüloz Kolon Kromatografisi}

Kanlıca mantarı ham ekstresinde tirozinazı çöktüren uygun amonyum sülfat konsantrasyonunun \% 60 olduğu belirlendi.

$100 \mathrm{mM}$ fosfat eluatının DEAE-selüloz kolonuna uygulanması sonucunda tirozinazın $1 \mathrm{mM}$ $\mathrm{NaCl} / 0,5 \mathrm{M}$ fosfat tamponu ile tek pik şeklinde olduğu gözlemlendi (Şekil 1). 


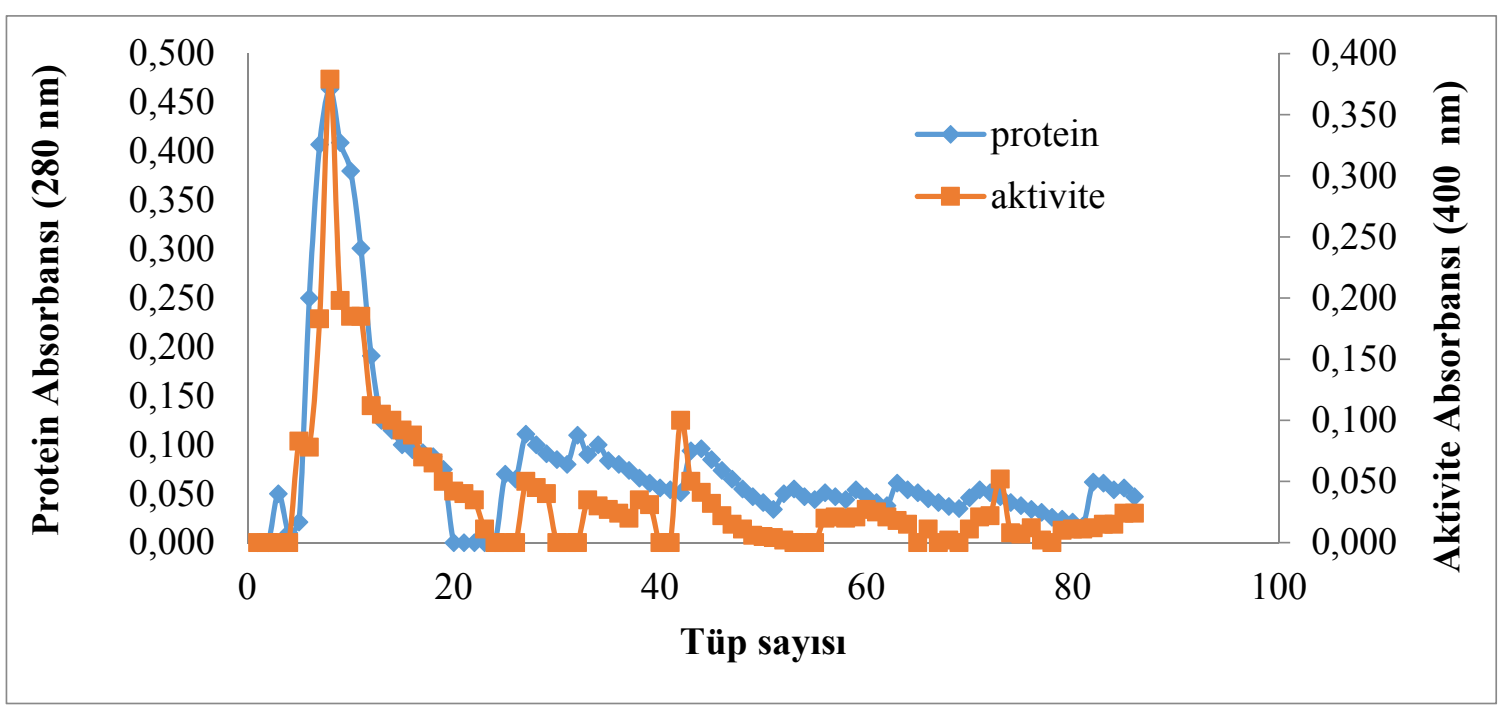

Şekil 1. Kanlıca Mantarı Ham Ekstresinin \% 60 Amonyum Sülfat Fraksiyonunun DEAE-Selüloz Kolon Kromotografisi Elüsyon Grafiği

(Kolon Boyutu: 1.4x10 cm; Kolona uygulanan protein: $200 \mathrm{mg} / \mathrm{mL}$;Elüsyon tamponlar1: pH's1 7,0 olan 0,5 mM sodyum fosfatta çözülmüş $10,20,30,50,100,200,300$ ve $500 \mathrm{mM} \mathrm{NaCl}$ )

Kanlıca Mantarından tirozinazın saflaştırılma evreleri ve bu evrelere ait sonuçlar Tablo 1'de gösterildi. Çalışmamızda Kanlıca mantarı ham ekstresi hazırlama, amonyum sülfat kesiti, DEAEselüloz kolon kromatografisi evrelerinde tirozinaz aktivitesi tayin edildi. Kanlıca mantarından tirozinaz enzimi DEAE-selüloz kolon kromatografisi sonucu 178,33 kat saflaştırıldı (Tablo 1).

Tablo 1. Kanlıca mantarından tirozinazın saflaştırılma basamakları

\begin{tabular}{lcccc}
\hline $\begin{array}{l}\text { İşlem } \\
\text { Evreleri }\end{array}$ & $\begin{array}{c}\text { Total Protein } \\
(\mathrm{mg})\end{array}$ & $\begin{array}{c}\text { Total Aktivite } \\
(\mathrm{U})\end{array}$ & $\begin{array}{c}\text { Spesifik Aktivite } \\
(\mathrm{U} / \mathrm{mg})\end{array}$ & $\begin{array}{c}\text { Saflaştırma } \\
\text { Oranı }\end{array}$ \\
\hline Ham Ekstre & 28687 & 16725 & 13,11 & 1,03 \\
$\begin{array}{l}\text { \%60 Amonyum Sülfat Kesiti } \\
\text { Dializat }\end{array}$ & 2348 & 15845 & 13,49 & 1,15 \\
& 14582 & 9577 & 15,10 & 178,33 \\
$\begin{array}{l}\text { DEAE-Selüloz Kolon } \\
\text { Kromatografisi }\end{array}$ & & & 2338 & \\
\hline
\end{tabular}




\subsection{SDS-PAGE Elektroforezi}

Saflaştırılan tirozinaz enziminin SDS-PAGE uygulanarak tek protein bandı içerdiği saptandı. Molekül ağırlığı tayininde kullanılan standart proteinler ile çizilen eğriden tirozinaz molekül ağırlığının $30 \mathrm{kDa}$ olduğu saptandı. (Şekil 2).

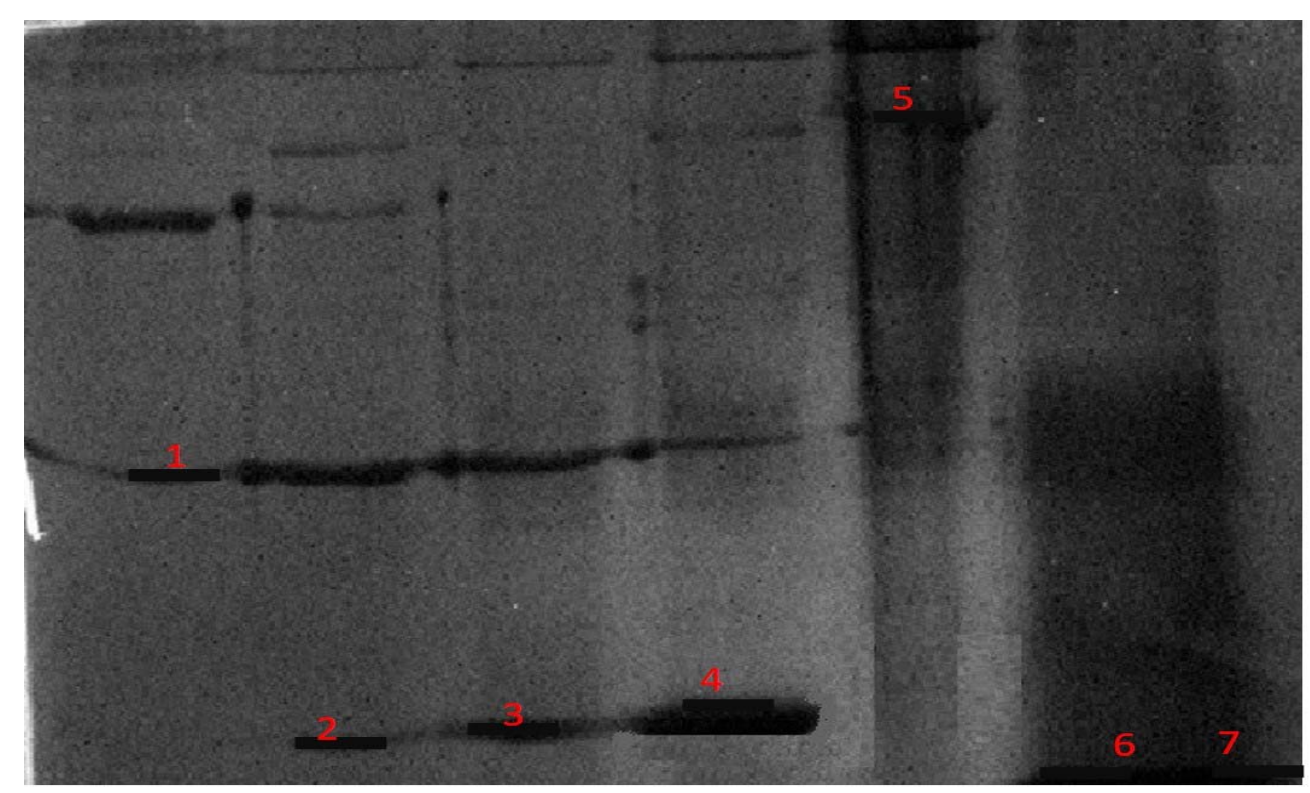

Şekil 2. SDS-PAGE jel elektroforezi

(1. Bovine serum albumin $(\mathrm{Mr}=14.2 \mathrm{kDa}), 2$. Karbonik anhidraz $(\mathrm{Mr}=29 \mathrm{kDa})$, 3. Serum albumin $(\mathrm{Mr}=$ $45 \mathrm{kDa}), 4$. $\alpha$-laktalbumin $(\mathrm{Mr}=132 \mathrm{kDa})$, 5. Üreaz $(\mathrm{Mr}=272 \mathrm{kDa}), 6$. Ham ekstre, 7. DEAE-selüloz kolon çıkışlı enzim çözeltisi)

\subsection{Tirozinaz Aktivitesine pH'nın Etkisi}

Tirozinaz enziminin maksimum aktivite gösterdiği optimum $\mathrm{pH}$ değerini belirlemek amacı ile değişik pH değerlerinde (3-10 aralığı) L-tirozin kullanılarak reaksiyon hızları belirlendi. Elde edilen değerlerden yararlanılarak aktiviteler hesaplandı. Böylece tirozinaz enzimi için optimum $\mathrm{pH}$ değerleri tespit edildi (Şekil 3). 


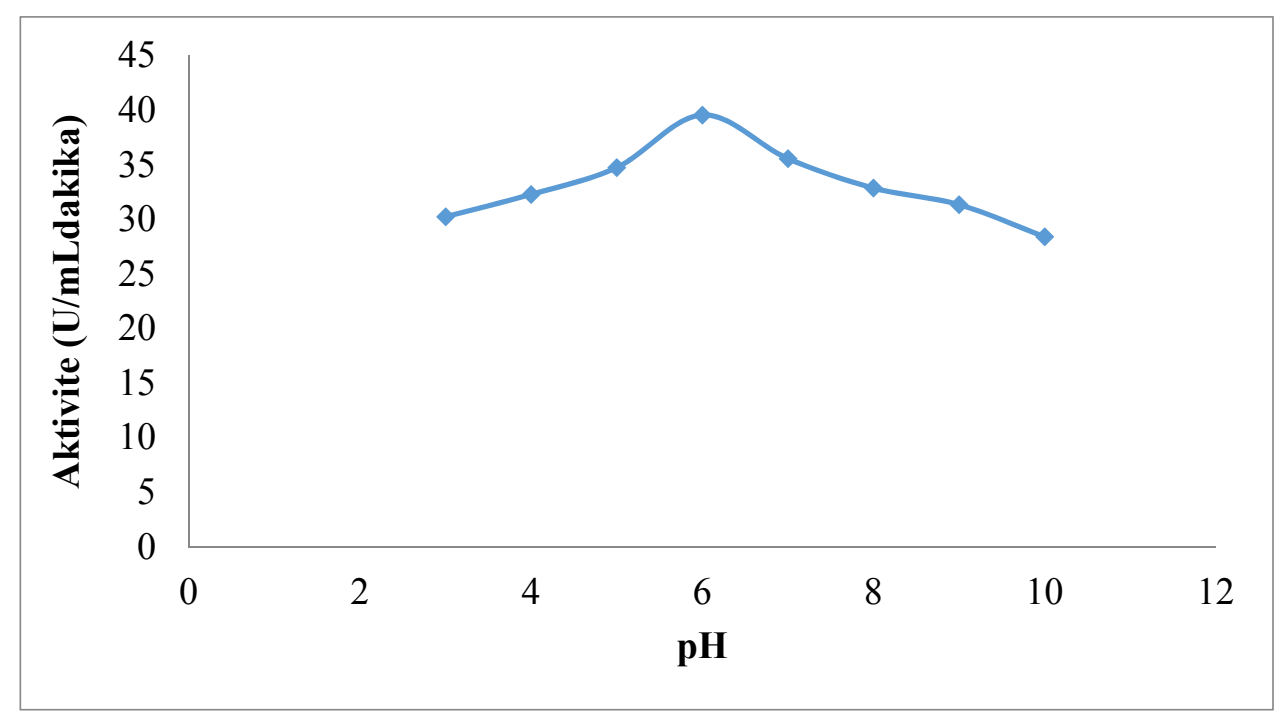

Şekil 3. Tirozinaz Aktivitesi Üzerine pH’nın Etkisi

\subsection{Tirozinaz Aktivitesine Sıcaklığın Etkisi}

Tirozinaz enziminin aktivitesi üzerine sıcaklığın etkisinin belirlenmesi amacıyla L-tirozin kullanılarak 20-70 ${ }^{\circ} \mathrm{C}$ 'deki reaksiyon hızları belirlendi. Elde edilen verilerden yararlanarak aktiviteler hesaplandı. Böylece tirozinaz enzimi için optimum sıcaklık değeri belirlendi (Şekil 4).

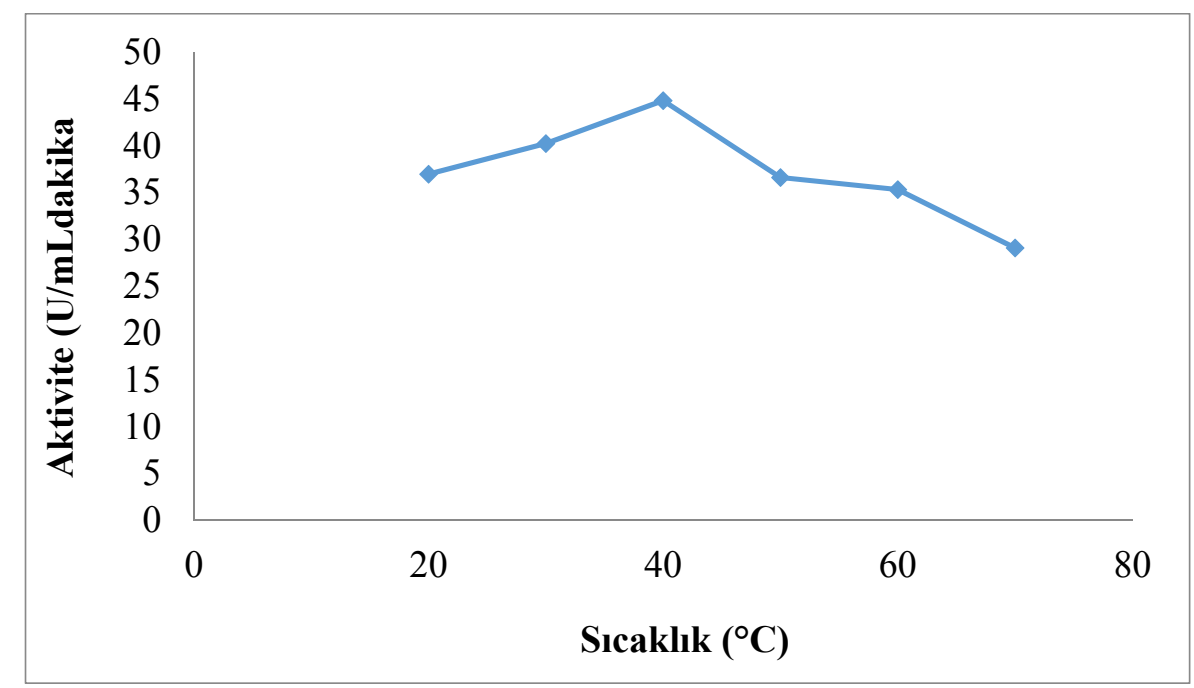

Şekil 4. Tirozinaz Aktivitesi Üzerine Sıcaklığın Etkisi

\subsection{Uygun Reaksiyon Süresinin Bulunması}

Tirozinaz aktivitesinin 1, 5, 10, 15, 20, 25 ve 30. dakikalarındaki reaksiyonlar sonucunda aktivitenin zamana bağlı olarak arttığı saptandı. Ancak aktivitede artışın 5. dakikada başlaması nedeni ile aktivite tayininde 5 dakikada ölçümlerin yapılmasına karar verildi (Şekil 5). 


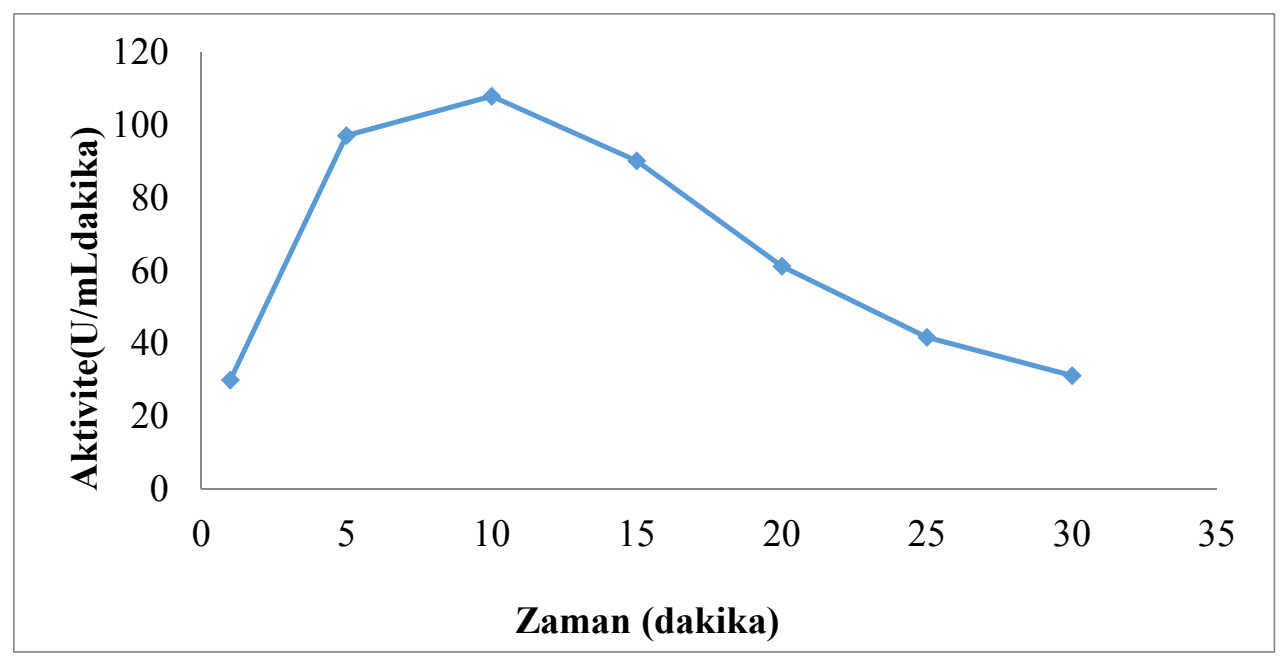

Şekil 5. Zamanın Tirozinaz Aktivitesine Etkisi

\subsection{Tirozinaz Enziminin $K_{m}$ ve $V_{\max }$ Değerlerinin Bulunması}

Tirozinaz enziminin $\mathrm{K}_{\mathrm{m}}$ ve $\mathrm{V}_{\max }$ değerleri Lineweaver-Burk denkleminden yararlanılarak hesaplandı (Şekil 6).

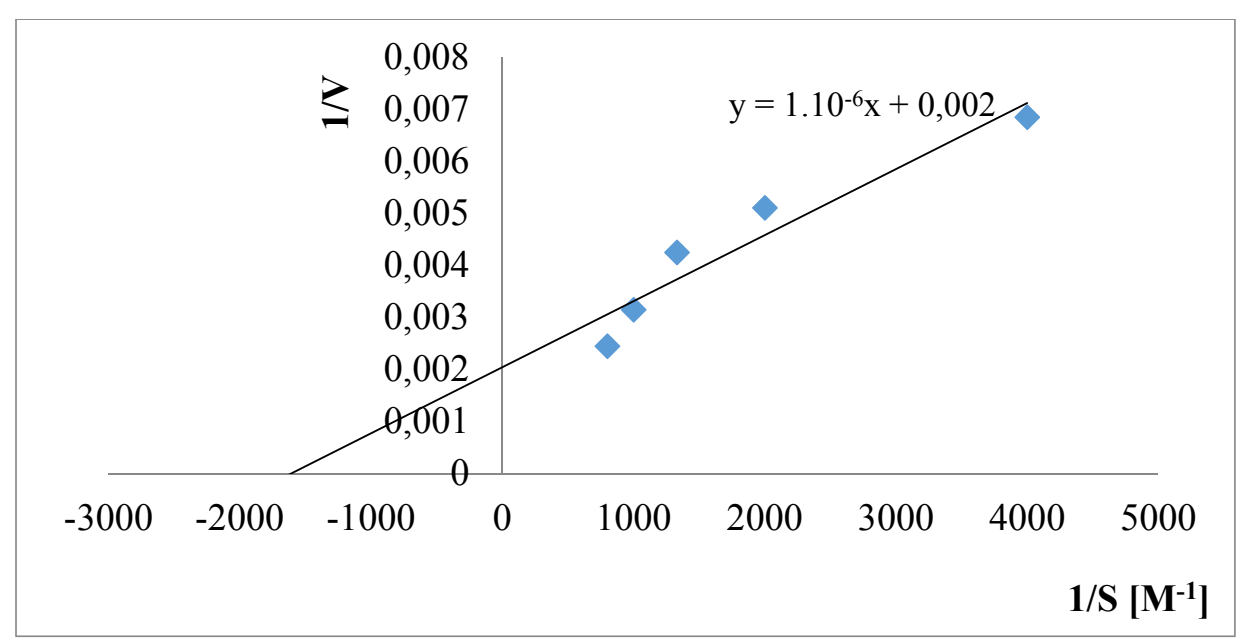

Şekil 6. Tirozinaz Enziminin $K_{m}$ ve $V_{\max }$ Değerlerinin Bulunmas1

\subsection{Enzim Konsantrasyonunun Tirozinaz Aktivitesine Etkisi}

180-1080 $\mu \mathrm{L}$ arasında değişen hacimlerde alınan enzim çözeltileriyle tirozinaz aktivitesi ölçümleri yapıldı. Enzim hacminin artması ile tirozinaz aktivitesinin arttığ görüldü. Ancak $720 \mu \mathrm{L}$ enzim hacminde aktivite belli bir değerde dengelendiği, daha fazla substrat miktarının aktiviteyi arttırmadı̆̆ı saptandı (Şekil 7). 


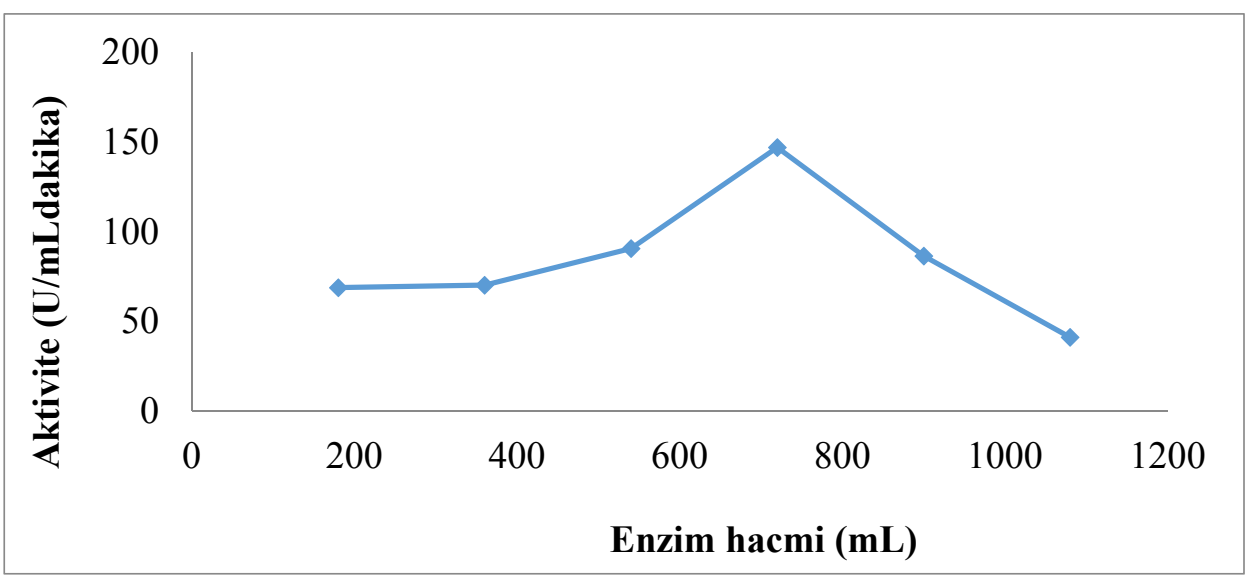

Şekil 7. Enzim Konsantrasyonunun Tirozinaz Aktivitesine Etkisi

\subsection{Substrat Konsantrasyonunun Tirozinaz Aktivitesine Etkisi}

180-1080 $\mu \mathrm{L}$ arasında değişen hacimlerde alınan enzim çözeltileriyle tirozinaz aktivitesi ölçümleri yapıldı. Enzim hacminin artması ile tirozinaz aktivitesinin arttığı görüldü. Ancak $720 \mu \mathrm{L}$ enzim hacminde aktivite belli bir değerde dengelendiği, daha fazla substrat miktarının aktiviteyi arttırmadığı saptandı (Şekil 8).

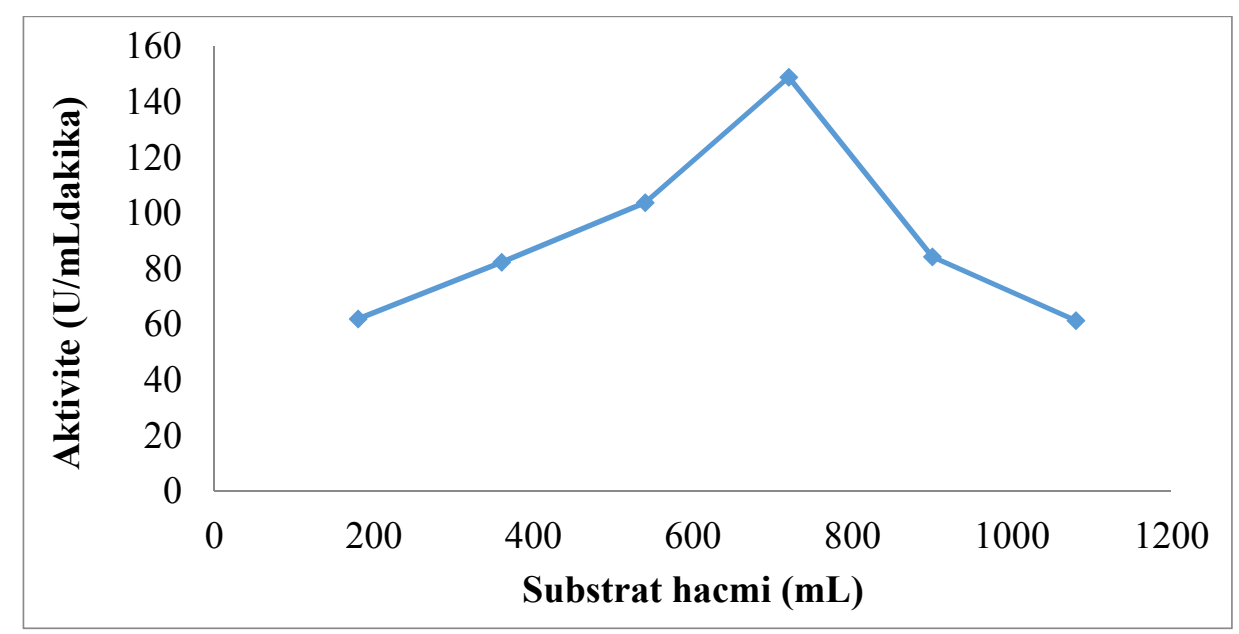

Şekil 8. Substrat Konsantrasyonunun Tirozinaz Aktivitesine Etkisi

Çeşitli endüstriyel işlemlerde kullanım alanlarına sahip olan tirozinazların, çeşitli bitki, meyve ve sebzeden saflaştırıldığı ve bazı kinetik özelliklerinin incelendiği saptanmıştır. Tirozinazın Kanlıca Mantarı'ndan saflaştırılması ile ilgili literatürde herhangi bir çalışmaya rastlanmamıştır. Bu çalışmada, Kanlıca Mantarı ilk kez saflaştırılmış ve bazı kinetik özellikleri incelenmiştir.

Yapılan bu çalışmada, L. salmonicolor mantarında bazı fenolik bileşiklerin yükseltgenmesinden sorumlu, oksidoredüktaz sınıfı bir enzim olan tirozinazın varlı̆̆ı ve biyokimyasal özellikleri ortaya konulmuştur. Bu amaçla; söz konusu mantarlardan hazırlanan enzim 
özütünden tirozinaz, sentezlenen bir afinite jeli kullanılarak yapılan afinite kromatografisiyle saflaştırılmıştır. Enzimin varlı̆̆ı, saf enzim elüatında elektroforetik olarak belirlenmiştir. Ayrıca, enzimin biyokimyasal, kinetik özellikleri araştırılıp, elde dilen veriler diğer organizmalarda çalışılan tirozinazlar ile karşılaştırılmıştır.

Enzimlerin çeşitli bitki, hayvan ve mikroorganizmalardan saflaştırılmasında, farklı yöntemler kullanılmaktadır. Bu yöntemlere göre çalışmalarda saflaştırma oranları da değişmektedir. Yapılan çalışmalarda tirozinaz, çaydan 3,32 kat (Kacar, 2010), Domat zeytininden 11,7 kat (Uylaşer ve ark., 2000) olarak saflaştırılmıştır. Çalışmamızda ise Kanlıca Mantarı'ndan tirozinaz 178,33 kat saflaştırılmıştır.

Meyve dokularından tirozinazı ekstrakte edebilmek için çeşitli tamponlar kullanılmaktadır ve pH değerleri enzim kaynağına bağlı olarak değişmektedir. Fakat pH, genelde az bazik bir ortam sağlayacak şekilde ayarlanır. Tamponun pH'sı elde edilen enzimin yapısını etkileyebilir. Araştırmamızda birçok literatürde belirtildiği gibi 200 mM, pH 7,0 fosfat tamponu kullanıldı.

Tirozinaz aktivitesi substratın tükenme veya ürünün oluşum hızının ölçülmesiyle belirlenebilir. Ürünün oluşum hızı kinonlardan oluşan renkli bileşiklerin absorbans değerlerinin ölçümü ile spektrofotometrik olarak belirlenebilir. Bu metot oldukça basittir ve rutin analizlerde kullanılır. Ayrıca bu metot diğer metotlar kadar hassas ve güvenilir olduğundan dolayı çalışmamızda tirozinaz aktivitesi $400 \mathrm{~nm}$ 'de spektrofotometrik olarak belirlenmiştir.

Enzimlerde, optimum pH değerleri, kullanılan materyalin kaynağına, ham enzim ekstresi hazırlama yöntemine ve kullanılan substrata göre farklılıklar gösterir (Jiang, 1999). Yapılan çalışmalarda Anamur muzunun optimum pH'sı 7,0 (Karlıdağ ve ark. 2007); çayın optimum pH'sı 6,02 (Kacar, 2010); kaldirik bitkisinin pH's1 5,0 (Güngör, 2008) olarak bulunmuştur. Bu nedenle, $\mathrm{pH}$, enzim aktivitesinin ifadesinde önemli bir faktördür. L. salmonicolor tirozinazının pH'ya bağımlılığı, 3,0-10,0 pH değerleri arasında incelendiğinde, grafiğin tek pik verdiği ve optimum pH'nın L-tirozin substratı kullanılarak 6,0 olduğu tespit edilmiştir. $\mathrm{Bu}$ sonuçlara göre, $L$. salmonicolor $\mathrm{pH}$ optimumu açısından uygunluk gösterdiği görülmektedir.

Bu çalışmada, sıcaklık ve pH göz önüne alındığında enzimin sıcaklığa dayanıklı bir enzim olduğu ve pH'ının da kararlı bir yapıda olduğu söylenebilir. Uygun enzim konsantrasyonu, substrat ve reaksiyon sürelerinin tayininde bulduğumuz değerler, enzim aktivitesinin uygun reaksiyon şartlarında yapıldığını göstermektedir.

Elde edilen sonuçlardan, ülkemizde yetişen ve yurt dışına ihraç edilen Kanlıca mantarından tirozinaz enziminin saflaştırılıp çeşitli endüstri alanlarında kullanılabileceği kanısına varılmıştır. 


\section{Sonuçlar ve Öneriler}

Yapılan literatür araştırmalarına göre tirozinaz enzimi çeşitli kaynaklardan saflaştırılmış olup bitki ve mantar olarak az sayıda kaynak kullanılmıştır. Literatürdeki bu boşluğu doldurmak adına yeni tirozinaz kaynaklarının araştırılmasına ihtiyaç duyulmaktadır. Bu boşluktan yola çıkılarak bu çalışmada, Giresun yöresinde yetişen bir mantar türü olan Kanlıca mantarından ilk kez tirozinaz enziminin saflaştırılması ve kinetik özelliklerinin incelenmesi, böylece literatüre bir katkı sağlanması amaçlanmıştır.

$\mathrm{Bu}$ çalışmada, tirozinaz enziminin saflaştırılması amacıyla Eylül-Ekim aylarında Giresun yöresinde yetişen Kanlıca mantarı kullanıldı. Giresun yöresinde yaygın olarak bulunan yenilebilir Kanlıca mantarı besin olarak tüketilmektedir. Bileşiminde fosfor, kalsiyum, demir, B, C vitaminleri, protein, karbonhidrat ve çok az miktarda da yağ bulunur. Kansızlığa ve zihinsel yorgunluğa iyi gelmektedir. Çok düşük kalorili olduğu için de kilo problemi yaratmamaktadır. Kolestrol düşürücü etkisi vardır, bağışıklık sistemini güçlendirici etkiye sahiptir. Antioksidan özelliği sayesinde vücuttaki toksinleri atmada etkilidir.

Literatürdeki bu boşluğu doldurmak adına yeni tirozinaz kaynaklarının araştırılmasına ihtiyaç duyulmaktadır. Bu boşluktan yola çıkılarak bu çalışmada, Giresun yöresinde yetişen bir mantar türü olan Kanlıca mantarından ilk kez tirozinaz enziminin saflaştırılması ve kinetik özelliklerinin incelenmesi, böylece literatüre bir katkı sağlanması amaçlanmıştır. Yapılan literatür araştırmalarına göre tirozinaz enzimi çeşitli kaynaklardan saflaştırılmış olup bitki ve mantar olarak az sayıda kaynak kullanılmıştır. Literatürdeki bu boşluğu doldurmak adına yeni tirozinaz kaynaklarının araştırılmasına ihtiyaç duyulmaktadır. Bu boşluktan yola çıkılarak bu çalışmada, Giresun yöresinde yetişen bir mantar türü olan Kanlıca Mantarı'ndan ilk kez tirozinaz enziminin saflaştırılması ve kinetik özelliklerinin incelenmesi, böylece literatüre bir katkı sağlanması amaçlanmıştır.

Giresun ve yöresinde yetişen yabani makro mantar tirozinazlarının varlı̆ğ, bu türden çalışmaların daha kapsamlı bir şekilde yapılıp, endüstriyel uygulamalar için kullanışlı olabileceği açısından önem arz etmektedir. Bu kaynaklardan tirozinazların saflaştırılması ile çeşitli ve yeni bazı polimerlerin veya diğer kimyasal maddelerin sentezi işlemlerinde kullanılabilirliklerinin araştırılması hız kazanacaktır.

\section{Teşekkür}

Bu çalışma, Giresun Üniversitesi Bilimsel Araştırma Koordinasyon Biriminin FEN-BAP-C200515-15 numaralı projesi ile desteklenmiştir. 


\section{Kaynaklar}

Chen, J.S., Cheng-i, W., Marshall, M.R. (1991). Inhibition Mechanism of Kojisc Acid on Polyphenol Oxidase, Journal of Agricultural and Food Chemistry, 39 (11), 1897-1901.

Güngör, K. (2008). Çağla Badem (Prunus dulcis) Bitkisinden Polifenol Oksidaz Enziminin Saflaştırılması ve Karakterizasyonu, Yüksek Lisans Tezi, Sakarya Üniversitesi, Fen Bilimleri Enstitüsü, Sakarya.

Jiang, Y.M. (1999). Purification and Some Properties of Polyphenol Oxidase of Longan Fruit, Food Chemistry, 66: 75-79.

Kacar, B.( 2010). Çay Bitkisi Biyokimyası Gübrelenmesi İşleme Teknolojisi. Nobel Yayın Dağıtım, Ankara, $355 \mathrm{~s}$.

Karlıdağ, H., Eşitken, A., Turanç, T., Şahin, F. (2007). Effects of Root İnoculation of Plant Growth Promoting Rhizbacteria (PGPR).

Keleş, F. (1987). Gidalarda Enzimatik Esmerleşme ve Kontrolü, Doğa Dergisi, 11,105-121

Laemmli, U. K. (1970). Cleavage of Structural Proteins During the. Aassembly of the Head of Bacteriofage T4. Nature, 227, 680-685.

Laurila, E., Kervinen, R., Ahvenainen, R. (1998). The Inhibition of Enzymatic Browning in Minimally Processed Vegatables and Fruits, Postharvest News and Information, 9 (4), 53-66.

Linnaeus, C. (1753). Species Plantarum: Tomus II. Holmiae. (Laurentii Salvii), pp. 1172.

Lowry, O.H., Rosebrough, N.J., Farr, A.L., Randall, R.J. (1951). Protein Measurement with Folin Phenol Reagent, Journal of Biological Chemistry, 193, 265-275.

Polaina, J.,MacCabe, A. P.( 2007). Industrial Enzymes: Structure, Applications of Quadratic Functions, 17, 250-255.

Ramsbottom, J. (1953). Mushrooms\&Toadstools. Collins. ISBN.

Rodriguez, C. S., Herrera T. (2006). Industrial and Biotechnological Applications of Laccases: Areview, Biotechnology Advances, 24, 500-513.

Spille, G. A. (1997). Caffeine, Chapter 3. Tea: The Plant and Its Manufacture; Chemistry and Consumption of the Beverage, CRC Press, 1-38.

Şimşek, Ş., Yemenicioğlu, A. (2007). Partial Purification and Kinetic Characterization of Mushroom Stem Polyphenol oxidase and Determination of its Storage Stability in Different Lyophilized Forms, Process Biochemistry, 42, 943-950.

Uylaşer, V., Korukluoğlu, M., Göçmen, D., Yıldırım, A., Şahin, İ. (2000). Yeşil Zeytin Üretiminde Farklı Çeşit ve Uygulamaların Ürun Kalitesine Etkisi. Türkiye 1. Zeytincilik Sempozyumu, 6-9 Haziran Bursa, 222-226.

Ünal, M.Ü., Şener, A. ( 2006). Determination of Biochemical Properties of Polyphenol Oxidase from Emir Grape (Vitisvinifera L. Cv. Emir), Journal of Science Food Agriculture, 86, 2374-2379.

Ünal, M.Ü. (2007). Properties of Polyphenol Oxidase from Anamur Banana (Musacavendishii), Food Chemistry, 100, 909-913.

Vamos-Vigyazo, L. (1981). Polyphenol Oxidase and Peroxidase in Fruits and Vegetables, CRC Critical Reviews Food Science and Nutrition, 15, 49-127.

Warburg, O., Christian, W. (1941). Isolierungund Kristallinsation Des Garungsferments Enolase, Biochemische Zeitschrift, 310, 384-421. 